Urban Agriculture and City Sustainability II 39

\title{
URBAN HEAT ISLAND MITIGATION DUE TO ENHANCED EVAPOTRANSPIRATION IN AN URBAN GARDEN IN SAINT PAUL, MINNESOTA, USA
}

\author{
GASTON SMALL ${ }^{1 *}$, IVAN JIMENEZ ${ }^{1}$, MICHAEL SALZL ${ }^{1} \&$ PALIZA SHRESTHA $^{2}$ \\ ${ }^{1}$ Department of Biology, University of Saint Thomas, USA \\ ${ }^{2}$ Department of Ecology, Evolution, and Behavior, University of Minnesota, USA
}

\begin{abstract}
As a result of extensive urban development coupled with warming temperatures, urban heat islands (UHI) have become an important factor affecting energy consumption and human health in cities. Prior research has shown that evapotranspiration (ET) from urban vegetation can have a significant cooling effect, but there are relatively few direct measurements from urban vegetable gardens. We compared hourly temperature measurements during two summers (2017 and 2018) in a $750 \mathrm{~m}^{2}$ research garden at the University of St. Thomas (Saint Paul, Minnesota, USA) to hourly temperatures at the nearby Minneapolis-Saint Paul (MSP) International Airport, located $6 \mathrm{~km}$ to the south. We also quantified seasonal ET (June-October) in 132 garden plots and five reference turfgrass plots during the summers of 2017 and 2018. For both years, an increase in temperature of $1.00^{\circ} \mathrm{C}$ at the MSP airport resulted in an average increase of $0.55^{\circ} \mathrm{C}$ in the research garden. At temperatures greater than $22^{\circ} \mathrm{C}$, the garden was cooler on average compared to MSP airport. ET in the garden plots was significantly higher than in the grass reference plots both years, with means of $46 \mathrm{~cm}$ for garden plots compared to $19 \mathrm{~cm}$ for grass plots in 2017, and $51 \mathrm{~cm}$ for garden plots compared to $33 \mathrm{~cm}$ for grass plots in 2018 . These results are consistent with other research showing potentially large benefits of cooling through ET from urban gardens that are primarily aimed at crop production.
\end{abstract}

Keywords: urban agriculture, vegetation, temperature.

\section{INTRODUCTION}

As a result of extensive urban development coupled with warming temperatures, urban heat islands (UHI) have become an important factor affecting energy consumption and quality of life in cities. Reduced vegetation cover in urban areas relative to the surrounding region results in decreased evapotranspiration (ET), causing a reduction in latent heat consumption and thereby leaving more energy available as sensible heat, resulting in higher land surface temperatures [1]. There is a strong relationship between impervious surface cover and land surface temperature in cities [2], with streets being especially susceptible [3]. Likewise, vegetated areas in cities are known to reduce maximum temperature, for example [4], [5], and urban designers are increasingly calling for more greenspace to mitigate UHI effects [6].

Previous research has shown that evapotranspiration (ET) from urban vegetation can have a significant cooling effect in cities. For example, a large greenspace in London caused temperature reductions of $1.1^{\circ} \mathrm{C}$ on summer months, and a maximum of $4{ }^{\circ} \mathrm{C}$ observed on some nights, with cooling effects extending from $20-440 \mathrm{~m}$ from the edge of the greenspace [5]. Trees and shrubs reduced soil temperature by $5.7^{\circ} \mathrm{C}$ in a mid-sized city in the UK, which was $0.6^{\circ} \mathrm{C}$ warmer than nearby rural areas [7]. In Beirut, areas of the city with larger garden fractions have up to $6^{\circ} \mathrm{C}$ cooler temperatures compared to surrounding areas [8]. In addition to natural vegetation within cities, green roofs have been a focus of research on UHI mitigation [1], [9]. Green roofs cool individual buildings through a combination of ET, physical shading, and insulation, and also contribute to urban cooling [9], [10]. For

* ORCID: http://orcid.org/0000-0002-9018-7555 
example, a model simulating $50 \%$ green roof coverage in a city predicted temperature reductions of $2^{\circ} \mathrm{C}[9]$.

In addition to natural vegetation in cities and highly engineered green roofs, urban vegetable gardens represent another land use that has received somewhat less attention for UHI mitigation potential. Urban gardens may be similar or more extensive in area compared to green roofs; urban vegetable gardens have been estimated to account for $0.04 \%$ of land area in Chicago [11], 0.1\% of land area in Saint Paul, Minnesota [12], and 3.6\% of land area in Montreal [13]. For comparison, Chicago, a leading city in green roof technology, has approximately $0.5 \mathrm{~km}^{2}$ of vegetated square roofs in the $606 \mathrm{~km}^{2}$ metropolitan area [14], or $0.08 \%$ land coverage. Additionally, unlike other forms of urban greenspace, many urban vegetable gardens receive supplemental irrigation during dry periods, increasing potential evapotranspiration and associated cooling. The potential impact of urban gardens on UHI mitigation has been considered in some previous analyses [1], [15], but empirical data on ET and cooling from urban gardens are limited.

We analyzed data from summer months over two years from a large urban garden in Saint Paul, Minnesota, USA, to evaluate the extent of UHI mitigation. We hypothesize that elevated ET rates from the irrigated garden will result in cooling rates that exceed documented rates for natural urban vegetation and green roofs.

\section{METHODS}

\subsection{Garden description}

The research garden at the University of Saint Thomas (Saint Paul, Minnesota, USA) is located at $44^{\circ} 56^{\prime} 17^{\prime \prime} \mathrm{N}, 93^{\circ} 11^{\prime} 46^{\prime} \mathrm{W}$. The garden, established in 2011 , consists of 32 replicated $4 \mathrm{~m}^{2}$ research plots growing peppers, carrots, bush beans, and collard greens. Research plots receive annual inputs of compost (either manure compost or municipal compost, targeted either to crop nitrogen or phosphorus demand), synthetic fertilizer, or no inputs. Garden soil, on average, has $9.4 \%$ organic matter, compared to surrounding soil below turfgrass which has $5.1 \%$ organic matter. Additional plots are dedicated to crop production and pollinator habitat, with a total area of approximately $1000 \mathrm{~m}^{2}$. The garden is situated on a 1.8 ha park-like area with approximately $50 \%$ tree cover. The research garden is located $20 \mathrm{~m}$ from an adjacent classroom building, and $250 \mathrm{~m}$ from the Mississippi River.

\subsection{Temperature measurements}

Hourly temperature readings for the garden were collected using Decagon instruments/datalogger, installed at a height of $1.0 \mathrm{~m}$ near the center of the garden. To quantify potential UHI mitigation by the garden, we compared temperature data collected at the Minneapolis-Saint Paul International Airport (MSP), located $6.6 \mathrm{~km} \mathrm{SSW}$ of the garden. MSP data were taken from the Iowa State climate data repository (http://mesonet.agron.iastate.edu). Temperature measurements at MSP are made in an open, grassy area located $35 \mathrm{~m}$ from an airplane taxiway, $250 \mathrm{~m}$ from the nearest building, $3.2 \mathrm{~km}$ from the Minnesota River, $3.5 \mathrm{~km}$ from the Mississippi River, and $2.1 \mathrm{~km}$ from Lake Nokomis.

Paired hourly temperature observations from the research garden and MSP airport were compiled from 1 June-30 August for 2017 and 2018, and any hours with missing observations were not used. 2,144 paired observations (out of a possible 2,184) were used for 2017, and 2,180 paired observations were used for 2018 . 
Regression analysis (using JMP Pro 15) was used to determine the slope of the relationship between airport temperature observations and garden temperature observations.

\subsection{Evapotranspiration measurements}

Evapotranspiration was calculated for the 2017 and 2018 growing seasons (30 May 2017-18 October 2017; 24 May 2018-20 October 2018), as difference between water inputs (rainfall and supplemental watering) and water loss through leachate. Rainfall was measured using an ECRN-50 rain gauge with $1 \mathrm{~mm}$ resolution, connected to a EM50 data logger (Decagon Devices). Supplemental watering of garden was quantified by applying water for a set amount of time (typically 30 or 45 seconds) to each $4 \mathrm{~m}^{2}$ plot, and measuring the amount of time required to fill a $10 \mathrm{~L}$ bucket on each watering date. Water was distributed evenly across study plots. Turfgrass was not watered and received only ambient rainfall.

Leachate was quantified by weekly measurements of water volume collected in 128 lysimeters installed below each $1 \mathrm{~m}^{2}$ garden subplot, and five additional lysimeters installed below turfgrass around perimeter of research garden. Each lysimeter consisted of a funnel with diameter $11.8 \mathrm{~cm}$ (surface area $109.3 \mathrm{~cm}^{2}$ ) attached to a $1 \mathrm{~L}$ plastic bottle. The top of the funnel was buried to a depth of $10 \mathrm{~cm}$ (below the rooting zone). Flexible polymer tubing ran from the collection bottle to the soil surface, and stone wool was used to plug the hole in the funnel to prevent soil from entering the collection bottle. Water was removed from each lysimeter using a syringe weekly during the growing season (June-October), and the volume was measured using graduated cylinder. Lysimeters were replaced each growing season. Soil moisture was measured in all garden study plots and control turfgrass plots approximately three times per week during the growing season in 2017, using a General DSMM500 soil moisture meter.

\section{RESULTS}

\subsection{Temperature measurements}

The mean air temperature observed at the research garden during June-August 2017 was $22.6^{\circ} \mathrm{C}$, compared to $23.3^{\circ} \mathrm{C}$ for MSP airport. Airport temperature exceeded garden temperature in 1,286 paired observations in 2017, whereas garden temperature was greater in 855 observations. For summer 2018, mean air temperature in the research garden was $21.4^{\circ} \mathrm{C}$, compared to $22.1^{\circ} \mathrm{C}$ at the MSP airport. Airport temperature exceeded garden temperature in 1301 paired observations in 2018, whereas garden temperature was greater in 876 observations.

Regression analysis shows that an increase of $1.00^{\circ} \mathrm{C}$ at the MSP airport resulted in an average increase of $0.56 \pm 0.02^{\circ} \mathrm{C}$ (mean $\pm \mathrm{SE}$ ) in the research garden in 2017 (Fig. 1), and $0.55 \pm 0.02^{\circ} \mathrm{C}$ in 2018 (Fig. 2). Garden temperatures tended to be cooler than airport temperatures when airport temperatures exceeded $21^{\circ} \mathrm{C}$, and warmer than airport temperatures at temperatures below $21^{\circ} \mathrm{C}$ during the summer months.

\subsection{Evapotranspiration measurements}

During the 2017 growing season, the UST research garden received $48.1 \mathrm{~cm}$ ambient rainfall, and $15.2 \mathrm{~cm}$ supplemental watering. During the 2018 growing season, the garden received $62.1 \mathrm{~cm}$ ambient rainfall, and $12.6 \mathrm{~cm}$ supplemental watering. Despite receiving $20-30 \%$ 


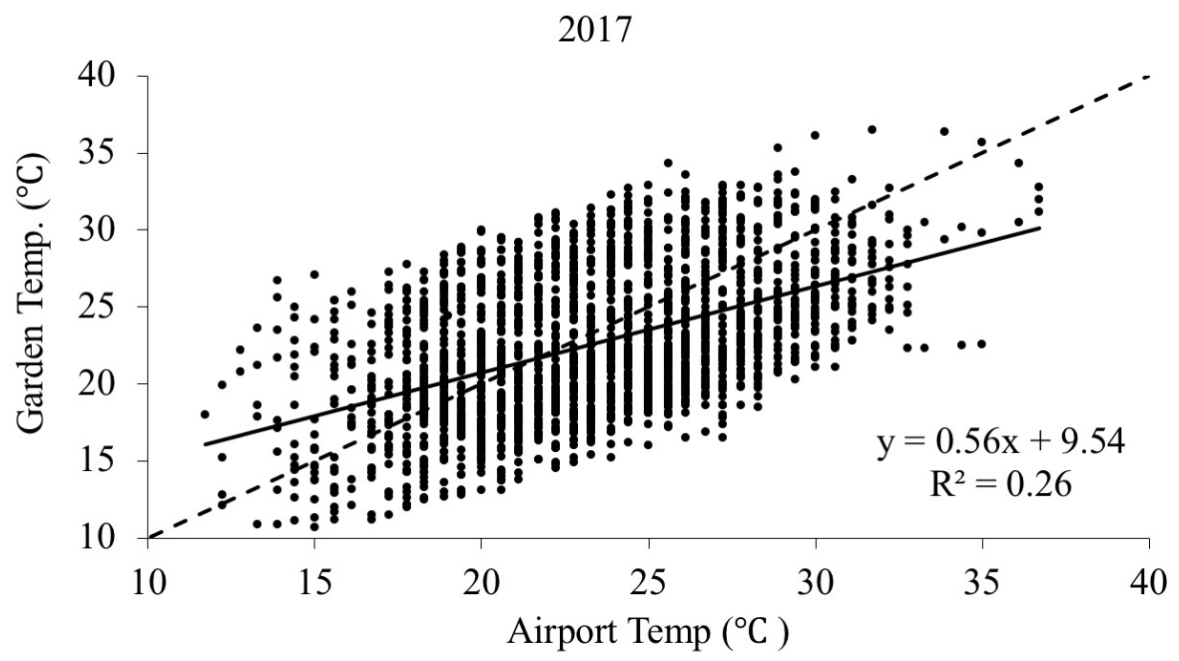

Figure 1: Relationship between measured hourly air temperature at the UST research garden and MSP airport during summer 2017. The solid line is a regression line; the dashed line is a 1:1 line.

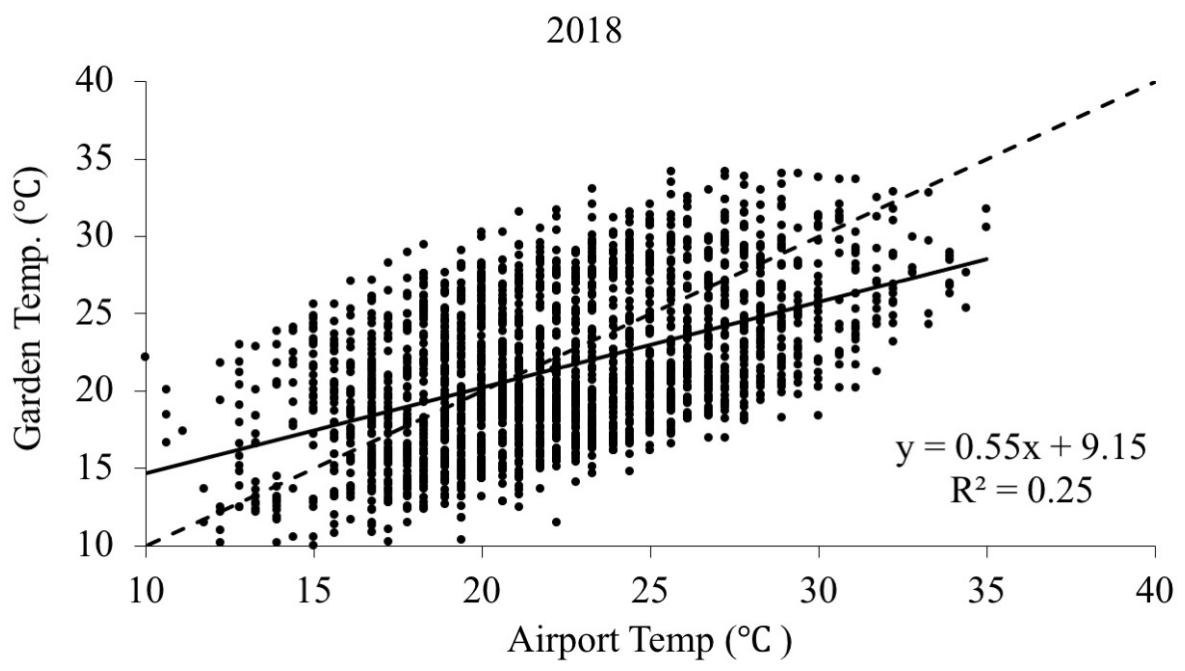

Figure 2: Relationship between measured hourly air temperature at the UST research garden and MSP airport during summer 2018. The solid line is a regression line; the dashed line is a 1:1 line.

higher water inputs due to supplemental watering, garden plots had leachate fluxes $20-40 \%$ lower compared to grass plots (Table 1). Estimated ET flux in garden plots was $140 \%$ greater than in grass plots in 2017, and 55\% greater in 2018 (Table 1). Soil moisture observations had a mean of $16.6 \%( \pm 0.1)$ in garden plots in 2017 , compared to $13.4 \%( \pm 1.4)$ in grass plots. 
Table 1: Water budgets for garden plots and grass plots from 2017 (30 May-18 October) and 2018 (24 May-20 October) growing seasons.

\begin{tabular}{lcccc}
\hline & $\begin{array}{c}\text { Garden plots } \\
\mathrm{n}=128 \text { mean }\end{array}$ & SE & $\begin{array}{c}\text { Grass plots } \\
\mathrm{n}=5 \text { mean }\end{array}$ & SE \\
\hline 2017 & & & & \\
Total rainfall (cm) & 48.1 & & 48.1 & \\
Supplemental watering (cm) & 15.2 & & 0.0 & \\
Total water input (cm) & 63.3 & & 48.1 & \\
Leachate (cm) & 16.8 & 1.0 & 28.6 & 4.8 \\
Evapotranspiration $(\mathrm{cm})$ & 46.5 & 1.0 & 19.5 & 4.8 \\
& & & & \\
2018 & & & & \\
Total rainfall (cm) & 62.1 & & 62.1 & \\
Supplemental watering (cm) & 12.6 & & 0.0 & \\
Total water input (cm) & 74.0 & & 62.1 & \\
Leachate (cm) & 23.7 & 0.9 & 29.2 & 6.3 \\
Evapotranspiration $(\mathrm{cm})$ & 51.0 & 0.9 & 32.9 & 6.3 \\
\hline
\end{tabular}

\section{DISCUSSION}

Our results support the hypothesis that elevated ET in an urban vegetable garden can contribute significantly to UHI mitigation, similar to cooling effects documented from green roofs and natural urban vegetation. Temperatures in the garden were moderated relative to airport temperatures, with a greater magnitude of cooling observed at higher temperatures. At temperatures above $21.7^{\circ} \mathrm{C}$ (in 2017) or $20.3^{\circ} \mathrm{C}$ (in 2018), garden temperatures tended to be cooler than temperatures at the MSP airport. For the warmest temperatures observed at MSP airport (approximately $35^{\circ} \mathrm{C}$ ), garden temperatures were, on average, nearly $6^{\circ} \mathrm{C}$ cooler.

Our results are consistent with the few other available empirical data on cooling effects of urban gardens. A study in Rosario, Argentina, found that the cooling effects of urban agriculture gardens of only 0.2 ha were similar to the effects of gardens and parks that were $2-3$ ha [16]. Likewise, the empirical data from our study is in agreement with results from a modeling study indicating that urban gardens can reduce surface temperatures by $5-10^{\circ} \mathrm{C}$ [15].

Evapotranspiration in garden plots was approximately double the rates observed in nearby turfgrass plots, potentially accounting for much of the observed cooling. While supplemental watering in the garden allowed for additional ET in garden plots, it is notable that cumulative leachate in garden plots was lower compared to turfgrass plots during both seasons, despite the additional water added. As a result, the total fraction of water inputs that are removed through ET is much higher in garden plots $(73.4 \%$ in 2017 and $68.9 \%$ in 2018 ) relative to turfgrass control plots (40.5\% in 2017 and $53.0 \%$ in 2018). The higher soil moisture observed in garden plots attests to the capacity of compost-amended garden soil to store water until it is used by plants. Many garden vegetable crops also have deeper root systems compared to turfgrass, allowing water to be extracted from deeper in the soil. Most leachate follows heavy 
rain events, when the capacity of the soil to retain water has been saturated. Because supplemental watering only occurs during relatively dry periods, the contribution to leaching is minimal; thus, ET is the fate of nearly all of this additional water. This finding is in agreement with the conclusions of Mariani et al. [17] which found that soil water reservoirs are important in UHI mitigation in urban parks. A synthesis of UHI data from 35 cities worldwide found that the effects of vegetative cooling increase sharply when ET exceeds $61.7 \mathrm{~mm} / \mathrm{month}$ [18]; ET in our garden plots exceeded $90 \mathrm{~mm} / \mathrm{month}$, compared to rates of $40-60 \mathrm{~mm} / \mathrm{month}$ for the turfgrass plots.

We cannot be sure that all cooling from the garden site was attributed to elevated ET in the garden itself; other factors, such as nearby tree cover or proximity to the Mississippi River may have also contributed to cooling. One study found cooling effects extending up to $300 \mathrm{~m}$ from a large river [19], but other studies have found more limited [20] or no [21] cooling effects of rivers. While our study has only two spatial data points, a spatially-intensive study in the Minneapolis-Saint Paul Metropolitan Area using 170 sensors shows that both the UST research garden and the MSP airport are well within the UHI zone [22], experiencing summer daytime mean temperatures approximately $1.0^{\circ} \mathrm{C}$ higher than surrounding rural areas. That study showed no discernable cooling effect of proximity to the Mississippi or Minnesota Rivers [22].

Our study provides some of the first empirical evidence showing that high ET from urban gardens dedicated to vegetable production may result in local UHI mitigation. Because green roofs and other urban green space generally do not receive supplemental irrigation, ET from vegetable gardens is likely to be greater, potentially magnifying the local cooling effect. Moreover, since urban vegetable gardens are more widespread and less costly than green roofs, their cumulative effect on UHI mitigation may be substantial, and deserves more attention. Importantly, there are many other ecosystem services documented from outdoor urban crop production [23], [24], so UHI mitigation is an added benefit which may contribute to more livable, sustainable cities.

\section{ACKNOWLEDGEMENTS}

This study was supported in part by a National Science Foundation CAREER award (award number 1651361) to G.E. Small. J. Abrahamson, H. Dare, K. Dennis, A. Gilmore, M. Hay, A. Johnson, W. Kreuser, E. Mahre, C. Monroe, G. Pahl, T. Schmitt, I. Tjokrosetio, and S. Wihlm assisted with data collection.

\section{REFERENCES}

[1] Qui, G., Li, H., Zhang, Q., Chen, W., Liang, X. \& Li, X., Effects of evapotranspiration on mitigation of urban temperature by vegetation and urban agriculture. Journal of Integrative Agriculture, 12, pp. 1307-1315, 2013.

[2] Yuan, F. \& Bauer, M.E., Comparison of impervious surface area and normalized difference vegetation index as indicators of surface urban heat island effects in Landsat imagery. Remote Sensing of Environment Volume, 106, pp. 375-386, 2007.

[3] Sharifi, E. \& Lehmann, S., Comparative analysis of surface urban heat island effect in central Sydney. Journal of Sustainable Development, 7, pp. 23-24, 2014.

[4] Wong, N.H. \& Yu, C., Study of green areas and urban heat island in a tropical city. Habitat International, 29, pp. 547-558, 2005.

[5] Doick, K.J., Peace, A. \& Hutchings, T.R., The role of one large greenspace in mitigating London's nocturnal urban heat island. Science of the Total Environment, 493, pp. 662-671, 2014. 
[6] Icaza, L.E. \& Van der Hoeven, F., Regionalist principles to reduce the urban heat island effect. Sustainability, 9, p. 677, 2017.

[7] Edmondson, J.L., Scott, I., Davies, G., Gaston, K.J. \& Leake, J.R., Soil surface temperatures reveal moderation of the urban heat island effect by trees and shrubs. Scientific Reports, 6, 33708, 2016.

[8] Kaloustian, N. \& Diab, Y., Effects of urbanization on the urban heat island in Beruit. Urban Climate, 14, pp. 154-165, 2015.

[9] Oberndorfer, E. et al., Green roofs as urban ecosystems: Ecological structures, functions, and services. BioScience, 57, pp. 823-833, 2007.

[10] Lee, J.S., Kim, J.T. \& Lee, M.G., Mitigation of urban heat island effect and greenroofs. Indoor and Built Environment, 23, pp. 62-69, 2013.

[11] Taylor, J.R. \& Lovell, S.T., Urban home food gardens in the global north: Research traditions and future directions. Agriculture and Human Values, 31, pp. 85-305, 2014.

[12] Small, G., Shrestha, P., Metson, G.S., Polsky, K., Jimenez, I. \& Kay, A., Excess phosphorus from compost applications in urban gardens creates potential pollution hotspots. Environmental Research Communications, 1, 091007, 2019.

[13] Metson, G.S. \& Bennett, E.M., Phosphorus cycling in Montreal's food and urban agricultural systems. PLoS One, 10, e0120726, 2015.

[14] City of Chicago, Chicago green roofs, 2020. www.chicago.gov/city/en/depts/dcd/ supp_info/chicago_green_roofs.html. Accessed on: 13 Jan. 2020.

[15] Tsilini, V., Papantoniou, S., Kolokots, D.-D. \& Maria, E.-A., Urban gardens as a solution to energy poverty and urban heat island. Sustainable Cities and Society, 14, pp. 323-333, 2015.

[16] Coronel, A.S. et al., Effects of urban green areas on air temperature in a medium-sized Argentinian city. AIMS Environmental Science, 2, pp. 803-825, 2015.

[17] Mariani, L., Parisi, S.G., Cola, G., Lafortezza, R., Colangelo, G. \& Sanesi, G., Climatological analysis of the mitigating effects of vegetation on the urban heat island of Milan, Italy. Science of the Total Environment, 569, pp. 762-773, 2016.

[18] Su, Y. et al., Phenology acts as a primary control of urban vegetation cooling and warming: A synthetic analysis of global site observations. Agricultural and Forest Meteorology, 280, 107765, 2020.

[19] Murakawa, S., Sekine, T., Narita, K.I. \& Nishina, D., Study of the effects of a river on the thermal environment in an urban area. Energy and Buildings, 16, pp. 993-1001, 1991.

[20] Hathway, E.A. \& Sharples, S., The interaction of rivers and urban form in mitigating the urban heat island effect: A UK case study. Building and Environment, 58, pp. 1422, 2012.

[21] Moyer, A. \& Hawkins, T.W., River effects on the heat island of a small urban area. Urban Climate, 21, pp. 262-277, 2017.

[22] Smoliak, B.V., Snyder, P.K., Twine, T.E., Mykleby, P.M. \& Hertel, W.F., Dense network observations of the Twin Cities canopy-layer urban heat island. Journal of Applied Meterology and Climatology, 54, pp. 1899-1917, 2015.

[23] Ackerman, K., Dahlgren, E. \& Xue, X., Sustainable Urban Agriculture: Confirming Viable Scenarios for Production, New York State Energy Research and Development Authority: Albany, NY, 2013.

[24] Nogeire-McRae, T. et al., The role of urban agriculture in a secure, healthy, and sustainable food system. BioScience, 68, pp. 748-759, 2018. 